\title{
Elintarviketuotannon globaali rakennekehitys, alueellinen sijoittuminen ja politiikat
}

Tapani Yrjölä

Pellervon taloudellinen tutkimuslaitos PTT, Eerikinkatu 28 A, 00180 HELSINKI, tapani.yrjola@ptt.fi

Suomen maatalouspolitiikka on viime vuosikymmeninä kokenut merkittäviä muutoksia vain muutaman vuoden välein. Euroopan Unionin (EU) yhteisen maatalouspolitiikan ja kotimaisen maatalouspolitiikan yhteensovittaminen on ollut haasteellista. Lähivuosina aletaan valmistella EU:n yhteisen maatalouspolitiikan suuntaviivoja vuoden 2013 jälkeen. Tässä yhteydessä on tärkeää pohtia, minkälaisia politiikkavaihtoehtoja tulevaisuudessa voidaan toteuttaa ja mitä niistä seuraa suomalaiselle maa- ja elintarviketaloudelle.

Tässä tutkimuksessa keskitytään maatalouden ja elintarviketeollisuuden alueellisessa sijoittumisessa tapahtuviin muutoksiin ja niiden syihin selvittämällä kaupan vapauttamisen aiheuttamia muutoksia teollisuustuotannossa ja verrataan niitä elintarviketeollisuus- ja maataloustuotannossa tapahtuneisiin muutoksiin. Maataloustuotannossa tapahtuneita muutoksia käsitellään kahdella tasolla. Ensinnäkin kuvataan maataloustuotannossa maiden välisessä tuotantorakenteessa tapahtuneita muutoksia. Toiseksi kuvataan maiden sisäisessä tuotantorakenteessa tapahtuneita muutoksia.

Tutkimuksessa käytetään aineistona eri tilastontuottajien keräämiä tilastoja. Tilastot kattavat pääsääntöisesti ajan 1960-luvun alusta alkaen. Aineiston analysoimisessa on käytetty jakauman tasaisuutta kuvaavia menetelmiä, kuten Lorenzin käyriä ja niiden pohjalta laskettuja Gini-kertoimia.

Globalisaation myötä monien teollisuustuotteiden tuotanto on maailmanlaajuisesti keskittynyt selkeästi. Elintarviketeollisuuden tuotanto ei ole keskittynyt läheskään yhtä nopeasti. Maataloustuotanto puolestaan on jopa hajautunut, kun esimerkiksi maidontuotanto on päinvastoin hajaantunut ajan myötä yhä useampiin maihin. Maiden sisällä maataloustuotannossakin on tapahtunut alueellista keskittymistä.

Elintarviketeollisuus toimii niin suurelta osin koti- ja lähialuemarkkinoilla, ettei se keskity muun teollisuuden tavoin. Siksi teollisuustuotannon alueellisessa rakenteessa politiikkamuutosten seurauksena tapahtuneista muutoksia ei voida vetää johtopäätöksiä maa- ja elintarviketalouden vastaavista muutoksista. Elintarviketeollisuus on myös kytköksissä maataloustuotantoon, joskin jonkun verran keskittyneempää.

Maatalouden keskittymiskehitys on ollut Suomessa varsin samanlaista kuin muualla Euroopassa. Kokonaisuutena maatalous ei ole keskittynyt merkittävästi, mutta eri tuotantosuunnat ovat keskittyneet tietyille alueille. Erityisesti Suomessa politiikkamuutosten lisäksi markkinat, osaaminen, luonnon olosuhteiden tuomat rajoitteet ja väestörakenne vaikuttavat tuotannon alueelliseen sijoittumiseen. Politiikkamuutosten vaikutukset vaikuttavatkin olevan odotettua pienempiä. 


\section{Johdanto}

Satoja vuosia sitten Suomen maataloustuotanto oli jokseenkin määrin keskittynyttä. Ruoka tuotettiin, jalostettiin ja kulutettiin lähes samassa paikassa, joko itse maatilalla tai sen välittömässä läheisyydessä. Suurin osa väestöstä asui rannikolla tai sen välittömässä tuntumassa. Siksi maataloustuotanto ja elintarvikkeiden jalostus olivat keskittyneistä rannikkoseuduille, eikä jakautunut sielläkään tasaisesti.

Myöhemmin maata alettiin asuttaa laajemmin, kun ihmiset muuttivat kauemmas rannikolta ja lopulta käytännöllisesti katsoen maan joka kolkkaan. Maatalouden tuottamat elintarvikkeet kulutettiin kuitenkin edelleen tilojen välittömässä läheisyydessä. Tällöin maatalous- ja elintarviketuotanto oli hajaantunut melko tasaisesti koko maahan.

1900-luvulla keskittymiskehitys muutti suuntaansa. Niin maataloustuotanto kuin erityisesti elintarvikkeiden jalostuskin alkoivat keskittyä. Jokaisella tilalla ei enää ollut kaikkia tuotantosuuntia, vaan alettiin keskittyä yhteen tai muutamaan tuotantosuuntaan. Elintarvikejalostus keskittyi niin ikään. Kun esimerkiksi meijereitä vielä vuonna 1960 maassamme oli 382 meijeriä, oli niitä vuonna 2006 enää 60 .

Suomen maatalouspolitiikka on viime vuosikymmeninä kokenut merkittäviä muutoksia vain muutaman vuoden välein. Euroopan Unionin (EU) yhteisen maatalouspolitiikan ja kotimaisen maatalouspolitiikan yhteensovittaminen on ollut haasteellista. Kotimainen politiikka on kuitenkin jatkuvasti pyrkinyt kompensoimaan suomalaisen maatalouden pysyvän, olosuhteista aiheutuvan kilpailukykyhaitan, jotta kotimainen tuotanto voisi menestyä EU:ssa.

Lähivuosina aletaan valmistella EU:n yhteisen maatalouspolitiikan suuntaviivoja vuoden 2013 jälkeen. Tässä yhteydessä on tärkeää pohtia, minkälaisia politiikkavaihtoehtoja tulevaisuudessa voidaan toteuttaa ja mitä niistä seuraa suomalaiselle maa- ja elintarviketaloudelle. Maa- ja elintarviketalouden keskittymisellä saattaa olla huomattava merkitys aluetalouksille. Siksi niiden selvittäminen on tarpeellista.

Tässä tutkimuksessa keskitytään maatalouden ja elintarviketeollisuuden alueellisessa sijoittumisessa tapahtuviin muutoksiin ja niiden syihin selvittämällä kaupan vapauttamisen aiheuttamia muutoksia teollisuustuotannossa ja verrataan niitä elintarviketeollisuus- ja maataloustuotannossa tapahtuneisiin muutoksiin.

Maataloustuotannossa tapahtuneita muutoksia käsitellään kahdella tasolla. Ensinnäkin kuvataan maataloustuotannossa maiden välisessä tuotantorakenteessa tapahtuneita muutoksia. Tässä tarkastelussa huomioidaan maataloustuotteiden kauppaa koskevien sopimusten muutokset ja pohditaan niiden vaikutuksia maataloustuotantoon eri maissa. Toiseksi kuvataan maiden sisäisessä tuotantorakenteessa tapahtuneita muutoksia. Tässä tarkastelussa pohditaan miten eri maiden maatalouspolitiikoissa tapahtuneet muutokset ovat vaikuttaneet tilojen tuotannon ja maaseudun yleiseen monipuolisuuteen sekä tuotannon alueelliseen jakautumiseen maan sisällä.

\section{Aineisto ja menetelmät}

Tutkimuksessa käytetään aineistona Yhdistyneiden kansakuntien teollisuustilastoja (United Nations 2008) sekä eri maiden tilastoviranomaisten keräämiä maa- ja elintarviketalouden tilastoja. Tilastot kattavat pääsääntöisesti ajan 1960-luvun alusta alkaen.

Lorenzin käyrää käytetään kuvaamaan jakauman epätasaisuutta. Taloustieteissä sitä on yleisimmin käytettyä kuvaamaan tulonjaon tasaisuutta väestön keskuudessa. Tässä tutkimuksessa Lorenzin käyrien avulla tarkasteltiin tuotannon jakautumisen tasaisuutta alueiden välillä.

Lorenzin käyrä on koordinaatistossa pisteiden $(0,0)$ ja $(1,1)$ välille piirrettävä käyrä. Jos jakauma on täysin tasaisesti jakautunut, Lorenzin käyrä on suora pisteestä $(0,0)$ pisteeseen $(0,1)$. Mitä enemmän käyrä pullistuu suorasta poispäin, sitä epätasaisempi jakauma on. Täysin epätasaisesti jakaantuneet jakauman Lorenzin käyrän $\mathrm{y}=0$ kun $\mathrm{x}<1$ ja $\mathrm{y}=1$ kun $\mathrm{x}=1$. (Sen 1973)

Gini-kerroin perustuu Lorenzin käyrään. Kuviossa 1 esitetään Gini-kerroin graafisesti. Täydellisen tasaisesti jakautuneen jakauman ja Lorenzin käyrän rajoittama alueen (A) ja koko täydellisesti jakautuneen jakauman rajoittaman alueen $(A+B)$ suhde on Gini-kerroin. Siten Gini-kerroin voidaan esittää yhtälönä

$$
G=1-2 \int_{0}^{1} L(X) d X
$$

jossa L(X) on Lorenzin käyrä. Gini-kerroin saa arvoja välillä 0-1 ja jakauman epätasaisuuden kasvaessa arvot kasvavat. (Sen 1973) 


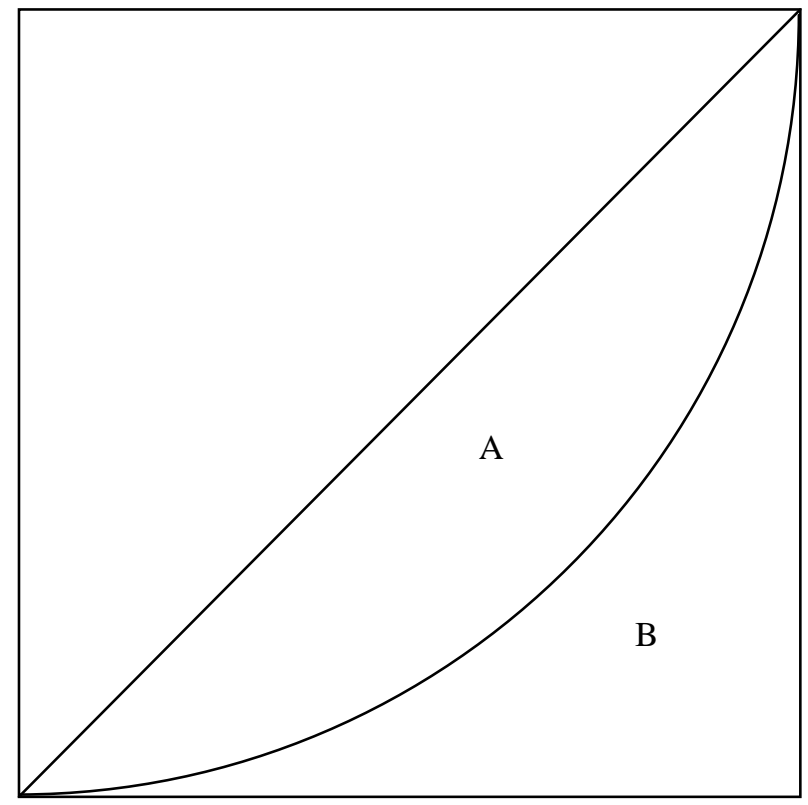

Kuvio 1. Lorenzin käyrä

\section{Tulokset ja tulosten tarkastelu}

Globalisaation myötä monien teollisuustuotteiden tuotanto on maailmanlaajuisesti keskittynyt selkeästi. Vielä 1970-luvulla esimerkiksi tekstiiliteollisuudesta oli merkittävä osuus Saksassa ja Japanissa. Nykyisin tekstiiliteollisuus on keskittynyt siten, että vuonna 2003 esimerkiksi miesten paidoista yhteensä 44\% tuotettiin Hong Kongissa, Romaniassa ja Brasiliassa. Gini-kertoimella mitattuna miesten paitojen tuotannon keskittyneisyys on kasvanut vuoden 1985 lukemasta 0,77 vuoteen 2003 mennessä lukemaan 0,86 .

Elintarviketeollisuuden tuotanto ei ole keskittynyt läheskään yhtä nopeasti. Esimerkiksi juustotuotannossa ei ole 1960-luvulta kuluvalle vuosikymmenelle tapahtunut mitään merkittäviä muutoksia. Vuonna 1964 suurimmat tuottajat olivat Yhdysvallat, Ranska, Saksa ja Italia, joiden yhteenlaskettu osuus koko maailman juustontuotannosta oli $49 \%$. Vuonna 2004 sama nelikko tuotti $53 \%$ kaikesta maailmassa tuotetusta juustosta ja miehitti edelleen tämän tilaston kärkisijat. Niiden alapuolellakaan minkään maan osuus ei ollut kasvanut merkittävästi. Juustontuotannon Gini-kerroin on pysynyt neljän vuosikymmenen ajan lähes muuttumattomana.

Maataloustuotanto puolestaan on jopa hajautunut, kun esimerkiksi maidontuotanto on päinvastoin hajaantunut ajan myötä yhä useampiin maihin. Saksan ja Yhdysvaltojen osuus kaikesta maailman maidontuotannosta on pienentynyt 1960-luvulta 2000-luvulle. Samaan aikaan erityisesti Intia ja Kiina, mutta myös Meksiko ja Uusi Seelanti ovat kasvattaneet osuuttaan. Maidontuotanto oli vuonna 1965 Gini-kertoimella mitattuna varsin keskittynyttä $(0,91)$. Vuoteen 2004 mennessä maidontuotanto oli hajautunut sen verran, että Gini-kertoimen arvo oli 0,84.

Maiden sisällä maataloustuotannossakin on tapahtunut alueellista keskittymistä. Esimerkiksi maidontuotantoa Yhdysvalloissa on viime vuosikymmeninä siirtynyt Keskilännestä ja itärannikolta muille tuotantoalueille. Kolmen suurimman maidontuottajaosavaltion osuus maan maidontuotannosta oli vuonna 1927 reilu neljännes, vuonna 1967 noin kolmannes ja vuonna 2007 jo yli 40 \%. Vuoden 2007 merkittävimmistä maidontuottajista toiseksi suurimman Wisconsinin ja kolmanneksi suurimman New Yorkin tuotanto oli osapuilleen kaksinkertaistunut 80 vuoden aikana, kun Kaliforniassa ja Idahossa maidontuotanto oli yli kymmenkertaistunut.

Maidontuotannon, samoin kuin koko maataloustuotannon, painopiste Yhdysvalloissa siirtyy jatkuvasti kohti länttä. Maidontuotannon Gini-kerroin 1960-luvun lopulla oli 0,63 ja kuluvan vuosikymmenen lopulla 0,69. Maidontuotanto on siis keskittynyt Yhdysvalloissa samalla kun sen osuus maailman hajautuvasta maidontuotannosta on pienentynyt.

Tanskassa maidontuotanto on kokonaistasolla pienentynyt varsin merkittävästi. Samalla tuotantoa on siirtynyt saarilta Jyllannin niemimaan eteläisiin osiin. Kun maidontuotanto Sjellannin saarella on pienentynyt noin viidennekseen vuosina 1970-2005, on se Etelä-Jyllannin ja Riben maakunnissa 
pienentynyt vain noin $20 \%$. Samalla maidontuotannon Gini-kerroin Tanskassa on noussut vuoden 1970 lukemasta 0,30 vuoden 2005 lukemaan 0,42.

Suomessa lehmämäärä on liki puolittunut vuodesta 1970 vuoteen 2005. Esimerkiksi Uudellamaalla ja Satakunnassa lehmämäärä oli pudonnut samalla aikavälillä noin neljännekseen. EteläPohjanmaalla lehmiä oli vuonna 2005 vain reilu viidennes vähemmän kuin vuonna 1970. Ginikertoimella mitattuna maidontuotannon keskittyneisyys sai vuonna 1970 varsin pienen arvon 0,25, joka vuoteen 2005 mennessä oli kasvanut lukemaan 0,35.

Myös Ruotsissa maidontuotanto on keskittynyt alueellisesti. Lehmämäärä on pienentynyt 35 vuoden aikana vuodesta 1970 liki puoleen. Suurimmilla tuotantoalueilla lehmämäärän pienentyminen on vastannut maan keskiarvoa, mutta muutamilla alueilla lehmämäärä on pienentynyt selvästi vähemmän. Gini-kertoimella mitattuna Ruotsin maidontuotanto hajautui vuosina 1970-1980, mutta on sen jälkeen keskittynyt, joskin Tanskaa ja Suomea hieman hitaammin.

\section{Johtopäätökset}

Elintarviketeollisuus toimii niin suurelta osin koti- ja lähialuemarkkinoilla, ettei se keskity muun teollisuuden tavoin. Siksi teollisuustuotannon alueellisessa rakenteessa politiikkamuutosten seurauksena tapahtuneista muutoksia ei voida vetää johtopäätöksiä maa- ja elintarviketalouden vastaavista muutoksista. Elintarviketeollisuus on myös kytköksissä maataloustuotantoon, joskin jonkun verran keskittyneempää.

Maatalouden keskittymiskehitys on ollut Suomessa varsin samanlaista kuin muualla Euroopassa. Kokonaisuutena maatalous ei ole keskittynyt merkittävästi, mutta eri tuotantosuunnat ovat keskittyneet tietyille alueille. Erityisesti Suomessa politiikkamuutosten lisäksi markkinat, osaaminen, luonnon olosuhteiden tuomat rajoitteet ja väestörakenne vaikuttavat tuotannon alueelliseen sijoittumiseen. Politiikkamuutosten vaikutukset vaikuttavatkin olevan odotettua pienempiä. Vaikka Euroopan unionilla onkin yhteinen maatalouspolitiikka, eri maissa on kuitenkin varsin erilaisia kansallisia maatalouspoliittisia ratkaisuja. Myös sillä perusteella vaikuttaa, että erilaiset politiikat eivät vaikuta kovin merkittävästi maataloustuotannon alueelliseen sijoittumiseen.

\section{Kirjallisuus}

Sen, Amartya. 1973. On Economic Inequality. Oxford: Oxford University Press.

Tilastokeskus. 2007. Suomen tilastollinen vuosikirja 2007. Helsinki: Tilastokeskus.

United Nations. 2008. Industrial Commodity Production Statistics Database. New York: United Nations, Statistics division. 